\title{
Assessment of HIV molecular surveillance capacity in the European Union, 2016
}

Patrick Keating ${ }^{1,2}$, Anastasia Pharris ${ }^{3}$, Katrin Leitmeyer ${ }^{3}$, Stefania De Angelis ${ }^{3}$, Annemarie Wensing ${ }^{4}$, Andrew J Amato-Gauci ${ }^{3}$, Eeva Broberg ${ }^{3}$

1. Österreichische Agentur für Gesundheit und Ernährungssicherheit (AGES), Vienna, Austria

2. European Programme for Intervention Epidemiology Training (EPIET), European Centre for Disease Prevention and Control (ECDC), Stockholm, Sweden

3. European Centre for Disease Prevention and Control (ECDC), Stockholm, Sweden

4. SPREAD/ESAR Programme, Luxembourg, Luxembourg

Correspondence: Patrick Keating (patrickbkeating1@gmail.com)

Keating Patrick, Pharris Anastasia, Leitmeyer Katrin, De Angelis Stefania, Wensing Annemarie, Amato-Gauci Andrew J, Broberg Eeva. Assessment of HIV molecular surveillance capacity in the European Union, 2016. Euro Surveill. 2017;22(49):pii=17-00269. https://doi.org/10.2807/1560-7917.ES.2017.22.49.17-00269

Introduction: Expanding access to HIV antiretroviral treatment is expected to decrease HIV incidence and acquired immunodeficiency syndrome (AIDS) mortality. However, this may also result in increased HIV drug resistance (DR). Better monitoring and surveillance of HIV DR is required to inform treatment regimens and maintain the long term effectiveness of antiretroviral drugs. As there is currently no formal European Union (EU)-wide collection of HIV DR data, this study aimed to assess the current HIV molecular surveillance capacity in EU/European Economic Area (EEA) countries in order to inform the planning of HIV DR monitoring at EU level. Methods: Thirty EU/EEA countries were invited to participate in a survey on HIV molecular surveillance capacity, which also included laboratory aspects. Results: Among 21 responding countries, 13 reported using HIV sequence data (subtype and/or DR) for surveillance purposes at national level. Of those, nine stated that clinical, epidemiological and sequence data were routinely linked for analysis. Discussion/conclusion: We identified similarities between existing HIV molecular surveillance systems, but also found important challenges including human resources, data ownership and legal issues that would need to be addressed.Information on capacities should allow better planning of the phased introduction of HIV DR surveillance at EU/EEA level.

\section{Introduction}

The World Health Organization's (WHO) 'Treat all' recommendation and the Joint United Nations Programmes on HIV/acquired immunodeficiency syndrome (AIDS) (UNAIDS) 90-90-90 strategy are clear demonstrations of the global commitment to end the HIV/AIDS epidemic by 2030 [1,2]. In 2015, UNAIDS estimated that $46 \%$ of people living with HIV globally were on antiretroviral therapy [3]. WHO also recommends providing pre-exposure prophylaxis (PrEP) to those at substantial risk of HIV infection [4]. These initiatives should lead to a reduction in HIV incidence and AIDS mortality, but greater access to treatment without complete adherence might also result in an increase in HIV drug resistance (DR) [5].

Aside from consistent adherence to the treatment regimen, HIV DR is influenced by a number of other factors, including HIV subtype, with certain subtypes showing more rapid onset of DR than others [6]. HIV DR mutations arise from genetic alterations caused by the error-prone HIV reverse transcriptase, which may then reduce the ability of specific drugs/classes of drugs to block replication of HIV [7-9]. HIV DR mutations are classified as either transmitted (TDR), when DR occurs in a combination antiretroviral treatment (CART, a combination of two or more different classes of antiretroviral drugs)-naïve HIV-infected individual, acquired (ADR), when DR is found in CART-experienced HIV-infected individuals, or pre-treatment (PDR), when resistance is detected in individuals starting CART, that was either transmitted or acquired due to a previous antiretroviral drug exposure [10].

Global surveillance of HIV DR was initiated by WHO in 2004 in order to monitor emergence of HIV DR, as access to cART was scaled up worldwide. Gupta et al. reported that over the period 2004-2010, prevalence of HIV DR among treatment-naive individuals greatly increased, particularly in southern and eastern Africa, at an estimated annual incremental increase of $14 \%$ and $29 \%$, respectively [5]. It is estimated by 2030 that if levels of PDR exceed $10 \%$ in sub-Saharan Africa, 890,000 AIDS deaths and 450,000 new HIV infections will be attributable to HIV DR [11]. Moreover, CART costs attributable to HIV DR could reach USD 6.5 billion. The WHO has led the development of the Global Action Plan on HIV DR (2017-2021) which is a call for action 
Main uses of HIV sequence data in European Union countries, $2016(n=21)$
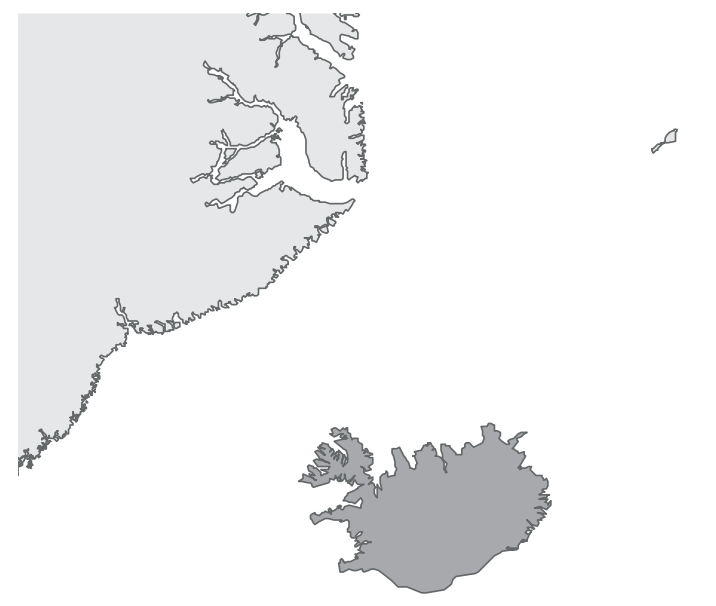

\section{Use of HIV sequence data}

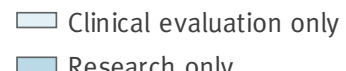

$\square$ Research only

$\square$ Surveillance only

$\square$ Research/clinical evaluation

Surveillance/clinical evaluation

- Surveillance/research

- Surveillance/research/clinical evaluation

- Unknown

$\square$ Did not participate in surveys

$\square$ Not included (non-EU/EEA country)

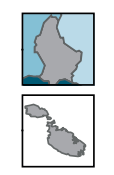

Luxembourg

Malta

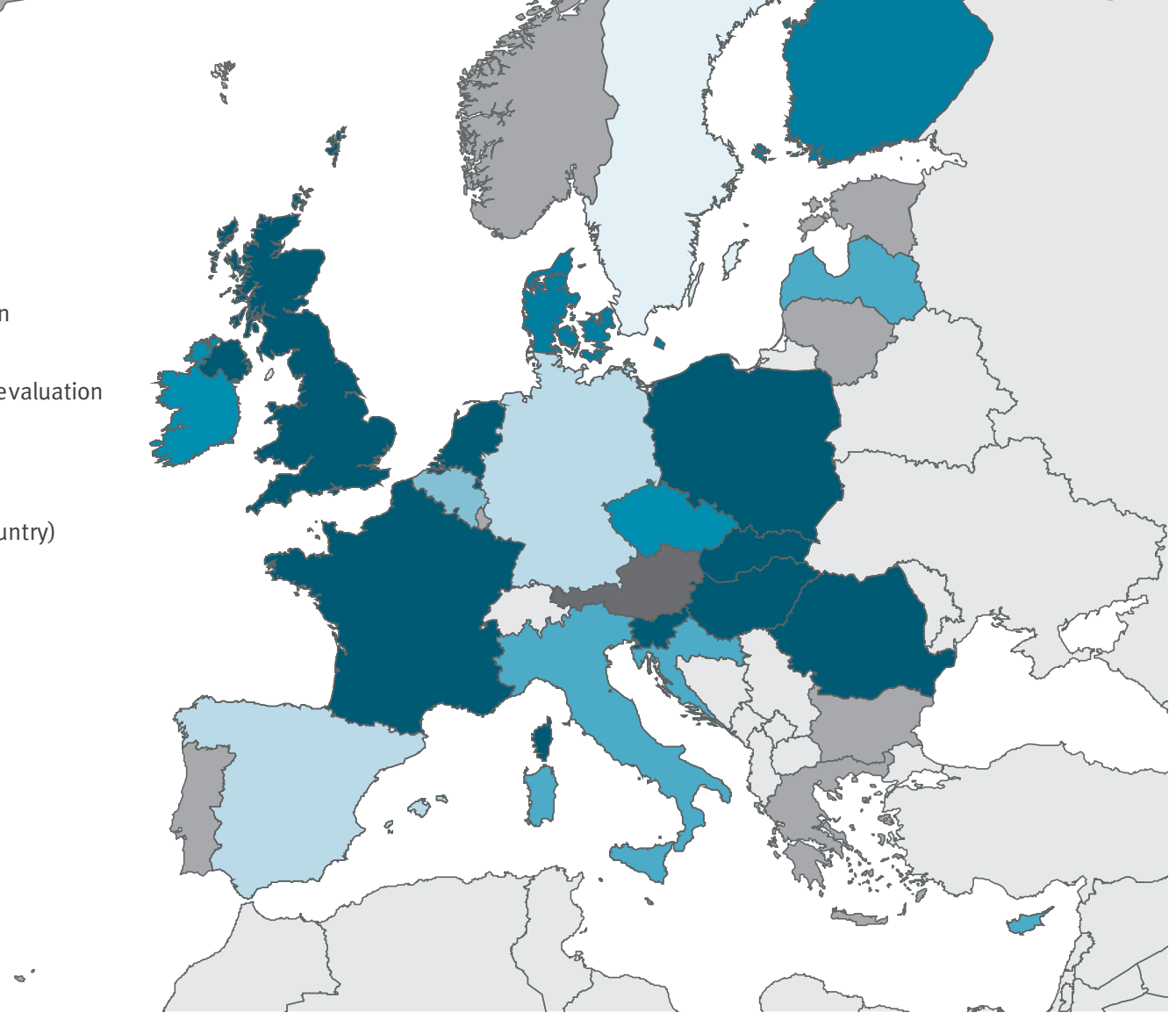

EEA: European Economic area; EU: European Union.

Administrative boundaries: EuroGeographics, UN-FAO.

to all stakeholders to monitor, prevent and respond to HIV DR [10]. WHO recommends that every national AIDS programme should have a robust HIV DR surveillance and monitoring strategy [12].

HIV DR also poses a public health challenge in the European Union (EU) and European Economic area (EEA). Reports from Strategy to Control SPREAD of HIV Drug Resistance (SPREAD), an EU-funded project that collected HIV DR data across Europe from 2002 to 2008 (and later years without funding), showed that approximately one in 10 patients with newly diagnosed HIV had a transmitted DR mutation [13,14]. Changes in HIV resistance over time have been reported to both influence the choice of antiretrovirals (which include the following drug classes: protease and integrase inhibitors as well as nucleotide and non-nucleotide reverse transcriptase inhibitors) by clinicians and reflect their use [15]. Changes in antiretroviral use are primarily based on resistance testing, rather than on surveillance data. 
TABLE 1A

Overview of molecular surveillance of HIV in European Union countries, $2016(n=21)$

\begin{tabular}{|c|c|c|c|c|c|c|c|c|c|}
\hline Country & $\begin{array}{c}\text { Collect HIV } \\
\text { sequence data } \\
\text { and use for } \\
\text { surveillance at } \\
\text { national level }\end{array}$ & $\begin{array}{l}\text { Patients selected } \\
\text { for sequence-based } \\
\text { characterisation in } \\
\text { clinical practice }\end{array}$ & $\begin{array}{l}\text { Collection of } \\
\text { HIV sequences }\end{array}$ & $\begin{array}{l}\text { Purpose of HIV } \\
\text { sequence data }\end{array}$ & $\begin{array}{l}\text { National } \\
\text { coverage } \\
\text { of HIV } \\
\text { sequence } \\
\text { data (\%) } \\
\end{array}$ & Data linkage & $\begin{array}{c}\text { Frequency } \\
\text { of reporting } \\
\text { of sequence } \\
\text { data }\end{array}$ & $\begin{array}{l}\text { National } \\
\text { HIV DR } \\
\text { report }\end{array}$ & $\begin{array}{l}\text { Submission } \\
\text { to SPREAD }\end{array}$ \\
\hline Austria & No & $\begin{array}{l}\text { Majority of HIV } \\
\text { patients }\end{array}$ & Not performed & Not applicable & No data & No, aggregated ${ }^{a}$ & NA & No & Yes \\
\hline Belgium & Yes & $\begin{array}{l}\text { CART-naive newly } \\
\text { HIV diagnosed }{ }^{\mathrm{b}} \text { and } \\
\text { cART-experienced } \\
\text { with HIV }\end{array}$ & $\begin{array}{l}\text { Cross- } \\
\text { sectional }\end{array}$ & $D^{e} /$ subtype $^{f}$ & No data & No, aggregated ${ }^{a}$ & Real-time & Yes & Yes \\
\hline Croatia & No & $\begin{array}{l}\text { Selected patient } \\
\text { groups (e.g. MSM } \\
\text { recently infected } \\
\text { abroad) and in all } \\
\text { treatment failures }\end{array}$ & Longitudinal $^{\mathrm{h}}$ & $\begin{array}{l}\mathrm{DR}^{\mathrm{e}} / \text { subtype }^{\mathrm{f}} / \\
\text { transmission }^{\mathrm{g}}\end{array}$ & 15 & $\begin{array}{l}\text { Complete or full } \\
\text { data linkage }\end{array}$ & NA & No & Yes \\
\hline Cyprus & No & $\begin{array}{l}\text { CART-naive newly } \\
\text { HIV diagnosed }{ }^{b} \text { and } \\
\text { cART-experienced } \\
\text { with HIVc }\end{array}$ & $\begin{array}{l}\text { Cross- } \\
\text { sectional }\end{array}$ & $\begin{array}{l}\text { DRe/subtype } / \\
\text { transmission }^{g}\end{array}$ & 100 & $\begin{array}{l}\text { Complete or full } \\
\text { data linkage }\end{array}$ & Annually & No & Yes \\
\hline $\begin{array}{l}\text { Czech } \\
\text { Republic }\end{array}$ & Yes & $\begin{array}{l}\text { CART-naive newly } \\
\text { HIV diagnosed }{ }^{\mathrm{b}} \text { and } \\
\text { cART-experienced } \\
\text { with HIV' and } \\
\text { upon request of a } \\
\text { physician }\end{array}$ & $\begin{array}{l}\text { Continually; } \\
\text { one sequence } \\
\text { per individual }\end{array}$ & $\mathrm{DR}^{\mathrm{e}} /$ subtype $^{\mathrm{f}}$ & 100 & $\begin{array}{l}\text { Complete or full } \\
\text { data linkage }\end{array}$ & Real-time & No & Yes \\
\hline Denmark & Yes & $\begin{array}{c}\text { Ca. } 70 \% \text { of cART- } \\
\text { naive newly HIV } \\
\text { diagnosed }{ }^{b} \text { and } \\
\text { a large proportion } \\
\text { of cART-experienced } \\
\text { with HIV } \\
\end{array}$ & $\begin{array}{l}\text { Cross- } \\
\text { sectional }\end{array}$ & $\begin{array}{l}\text { DRe/subtype } \\
\text { transmission }\end{array}$ & 70 & $\begin{array}{l}\text { Virological and } \\
\text { epidemiological } \\
\text { information can } \\
\text { be linked }\end{array}$ & Annually & Yes & Yes \\
\hline Finland & Yes & $\begin{array}{l}\text { CART-naive newly } \\
\text { HIV diagnosed }{ }^{\mathrm{b}} \text { and } \\
\text { CART-experienced } \\
\text { with HIV }{ }^{\mathrm{c}} \text { and } \\
\text { CART-naïve } \\
\text { initiating first line } \\
\text { CART' } \text { and } \\
\text { upon request of a } \\
\text { physician }\end{array}$ & $\begin{array}{l}\quad \text { Cross } \\
\text { sectional }{ }^{\mathrm{d} a n d} \\
\text { Longitudinal }^{\mathrm{h}}\end{array}$ & $\begin{array}{l}\mathrm{DR}^{\mathrm{e}} / \text { subtype }^{\mathrm{f}} / \\
\text { transmission }^{\mathrm{g}}\end{array}$ & 80 & $\begin{array}{l}\text { Complete or full } \\
\text { data linkage }\end{array}$ & Real-time & No & Yes \\
\hline France & Yes & $\begin{array}{l}\text { CART-naive newly } \\
\text { HIV diagnosed }{ }^{\mathrm{b}} \text { and } \\
\text { CART-experienced } \\
\text { with HIV' and } \\
\text { CART-naïve } \\
\text { initiating first line } \\
\text { CART' } \\
\text { and pregnant } \\
\text { women and source } \\
\text { patients with a } \\
\text { detectable HIV load }\end{array}$ & $\begin{array}{l}\text { Cross- } \\
\text { sectional }^{d}\end{array}$ & $\begin{array}{l}\mathrm{DR}^{\mathrm{e}} / \text { subtype }^{\mathrm{f}} / \\
\text { transmission }^{\mathrm{g}}\end{array}$ & No data & $\begin{array}{l}\text { Complete or full } \\
\text { data linkage }\end{array}$ & Annually & Yes & No data \\
\hline
\end{tabular}

CART: combination antiretroviral therapy; DR: drug resistance; MSM: men who have sex with men; NA: not available; SPREAD: Strategy to Control SPREAD of HIV Drug Resistance.

a Data are not linked and are available on an aggregated level only.

${ }^{b}$ All CART-naive individuals newly diagnosed with HIV.

c All cART-experienced individuals with a detectable HIV load.

d Only one sequence per individual is collected.

e Monitoring HIV DR.

${ }^{\mathrm{f}}$ Assess HIV subtypes.

${ }^{\mathrm{g}}$ Conduct phylogenetic analysis of transmission events.

${ }^{\mathrm{h}}$ Longitudinal in a cohort; multiple sequences per individual can be collected.

' Integrated clinical, epidemiological and virological data are submitted on a case-by-case level.

i All CART naïve individuals initiating first line cART.

${ }^{k}$ Clinical, epidemiological and laboratory variables from different databases are linked. 
Overview of molecular surveillance of HIV in European Union countries, $2016(n=21)$

\begin{tabular}{|c|c|c|c|c|c|c|c|c|c|}
\hline Country & $\begin{array}{l}\text { Collect HIV } \\
\text { sequence data } \\
\text { and use for } \\
\text { surveillance at } \\
\text { national level }\end{array}$ & $\begin{array}{l}\text { Patients selected } \\
\text { for sequence-based } \\
\text { characterisation in } \\
\text { clinical practice }\end{array}$ & $\begin{array}{l}\text { Collection of } \\
\text { HIV sequences }\end{array}$ & $\begin{array}{l}\text { Purpose of HIV } \\
\text { sequence data }\end{array}$ & $\begin{array}{l}\text { National } \\
\text { coverage } \\
\text { of HIV } \\
\text { sequence } \\
\text { data (\%) }\end{array}$ & Data linkage & $\begin{array}{c}\text { Frequency } \\
\text { of reporting } \\
\text { of sequence } \\
\text { data }\end{array}$ & $\begin{array}{l}\text { National } \\
\text { HIV DR } \\
\text { report }\end{array}$ & $\begin{array}{l}\text { Submission } \\
\text { to SPREAD }\end{array}$ \\
\hline Germany & No & $\begin{array}{l}\text { CART-experienced } \\
\text { with HIV' and } \\
\text { CART-naïve } \\
\text { initiating first line } \\
\text { CART' }\end{array}$ & $\begin{array}{l}\text { Cross- } \\
\text { sectionaldand } \\
\text { longitudinal }^{\mathrm{h}}\end{array}$ & $\begin{array}{l}\mathrm{DRe}^{\mathrm{e}} / \text { subtype }^{\mathrm{f}} / \\
\text { transmission }^{\mathrm{g}}\end{array}$ & No data & $\begin{array}{c}\text { Different } \\
\text { database } \\
\text { variables are } \\
\text { linked }^{k}\end{array}$ & Real-time & No & No \\
\hline Hungary & Yes & $\begin{array}{l}\text { CART-naive newly } \\
\text { HIV diagnosed }{ }^{\mathrm{b}} \text { and } \\
\text { CART-naïve } \\
\text { initiating first line } \\
\text { CART }^{\mathrm{i}}\end{array}$ & Longitudinal $^{\mathrm{h}}$ & $\begin{array}{l}\mathrm{DRe}^{\mathrm{e}} / \text { subtype }^{\mathrm{f}} / \\
\text { transmission }^{\mathrm{g}}\end{array}$ & No data & $\begin{array}{l}\text { Complete or full } \\
\text { data linkage }\end{array}$ & Monthly & Yes & No \\
\hline Ireland & Yes & $\begin{array}{l}\text { CART-naive newly } \\
\text { HIV diagnosed }{ }^{\mathrm{b}} \text { and } \\
\text { CART-naïve } \\
\text { initiating first line } \\
\text { CART' } \\
\text { and those with } \\
\text { detectable viral } \\
\text { load where a } \\
\text { regimen change is } \\
\text { considered }\end{array}$ & Longitudinal $^{\mathrm{h}}$ & $\begin{array}{l}\mathrm{DRe}^{\mathrm{e}} / \text { subtype }^{\mathrm{f}} / \\
\text { transmission }^{\mathrm{g}}\end{array}$ & 65 & $\begin{array}{l}\text { Complete or full } \\
\text { data linkage }\end{array}$ & Annually & Yes & No \\
\hline Italy & No & $\begin{array}{c}\text { Proportion of cART- } \\
\text { experienced with } \\
\text { HIV }^{c}\end{array}$ & Not applicable & $\begin{array}{l}\mathrm{DR}^{\mathrm{e}} / \text { subtype }^{\mathrm{f}} / \\
\text { transmission }^{\mathrm{g}}\end{array}$ & No data & No, aggregated ${ }^{a}$ & NA & No & No data \\
\hline Latvia & No & $\begin{array}{c}\text { cART-naïve } \\
\text { initiating first line } \\
\text { CART }^{\mathrm{i}}\end{array}$ & Not applicable & $\mathrm{DR}^{\mathrm{e}} /$ subtype $\mathrm{f}^{\mathrm{f}}$ & No data & No, aggregated ${ }^{a}$ & Real-time & No & No \\
\hline Netherlands & Yes & $\begin{array}{l}\text { CART-naive newly } \\
\text { HIV diagnosed }{ }^{\mathrm{b}} \text { and } \\
\text { CART-naïve } \\
\text { initiating first line } \\
\text { CART }^{\mathrm{i}}\end{array}$ & No data & $\begin{array}{l}\mathrm{DR}^{\mathrm{e}} / \text { subtype }^{\mathrm{f}} / \\
\text { transmission }^{\mathrm{g}}\end{array}$ & 35 & $\begin{array}{l}\text { Complete or full } \\
\text { data linkage }\end{array}$ & Annually & Yes & Yes \\
\hline Poland & Yes & $\begin{array}{l}\text { CART-experienced } \\
\text { with HIV' and } \\
\text { CART-naïve } \\
\text { initiating first line } \\
\text { CART' }\end{array}$ & Longitudinal $^{\mathrm{h}}$ & $\begin{array}{l}\mathrm{DR}^{\mathrm{e}} / \text { subtype }^{\mathrm{f}} / \\
\text { transmission }^{\mathrm{g}}\end{array}$ & 40 & $\begin{array}{c}\text { Partial data } \\
\text { submitted } \\
\text { to SPREAD } \\
\text { programme; } \\
\text { otherwise data } \\
\text { are not linked }\end{array}$ & Annually & No & Yes \\
\hline Romania & Yes & $\begin{array}{l}\text { Among some } \\
\text { patients with } \\
\text { virologic failure }\end{array}$ & Longitudinal $^{\mathrm{h}}$ & $\begin{array}{l}\mathrm{DR}^{\mathrm{e}} / \text { subtype }^{\mathrm{f}} / \\
\text { transmission }^{\mathrm{g}}\end{array}$ & No data & No, aggregated ${ }^{a}$ & NA & No & No \\
\hline
\end{tabular}

CART: combination antiretroviral therapy; DR: drug resistance; MSM: men who have sex with men; NA: not available; SPREAD: Strategy to Control SPREAD of HIV Drug Resistance.

a Data are not linked and are available on an aggregated level only.

${ }^{b}$ All CART-naive individuals newly diagnosed with HIV.

c All CART-experienced individuals with a detectable HIV load.

${ }^{d}$ Only one sequence per individual is collected.

e Monitoring HIV DR.

${ }^{f}$ Assess HIV subtypes.

${ }^{g}$ Conduct phylogenetic analysis of transmission events.

${ }^{\mathrm{h}}$ Longitudinal in a cohort; multiple sequences per individual can be collected.

' Integrated clinical, epidemiological and virological data are submitted on a case-by-case level.

i All CART naïve individuals initiating first line cART.

${ }^{k}$ Clinical, epidemiological and laboratory variables from different databases are linked.

Frentz et al. demonstrated that, over the period 2002 to 2007 , there was a significant decline in the prevalence of resistance mutations against protease inhibitors while the prevalence of resistance to non-nucleoside reverse transcriptase inhibitors doubled [13]. These significant changes over time in the prevalence of drug class-specific resistance mutations highlight the need for surveillance of HIV DR at the EU/EEA level to ensure the long-term effectiveness of antiretroviral drugs. 
TABLE 1C

Overview of molecular surveillance of HIV in European Union countries, $2016(n=21)$

\begin{tabular}{|c|c|c|c|c|c|c|c|c|c|}
\hline Country & $\begin{array}{l}\text { Collect HIV } \\
\text { sequence data } \\
\text { and use for } \\
\text { surveillance at } \\
\text { national level }\end{array}$ & $\begin{array}{l}\text { Patients selected } \\
\text { for sequence-based } \\
\text { characterisation in } \\
\text { clinical practice }\end{array}$ & $\begin{array}{l}\text { Collection of } \\
\text { HIV sequences }\end{array}$ & $\begin{array}{l}\text { Purpose of HIV } \\
\text { sequence data }\end{array}$ & $\begin{array}{l}\text { National } \\
\text { coverage } \\
\text { of HIV } \\
\text { sequence } \\
\text { data (\%) }\end{array}$ & Data linkage & $\begin{array}{l}\text { Frequency } \\
\text { of reporting } \\
\text { of sequence } \\
\text { data }\end{array}$ & $\begin{array}{l}\text { National } \\
\text { HIV DR } \\
\text { report }\end{array}$ & $\begin{array}{l}\text { Submission } \\
\text { to SPREAD }\end{array}$ \\
\hline Slovakia & Yes & $\begin{array}{l}50 \% \text { of each of the } \\
\text { following: } \\
\text { CART-naive newly } \\
\text { HIV diagnosed }{ }^{b} \text { and } \\
\text { CART-experienced } \\
\text { with HIV'c and } \\
\text { CART-naïve } \\
\text { initiating first line } \\
\text { CART' } \\
\text { and also individuals } \\
\text { with ART failure }\end{array}$ & $\begin{array}{l}\text { Cross- } \\
\text { sectional }^{d}\end{array}$ & $\begin{array}{l}\text { DRe/subtype } / \\
\text { transmission }^{\mathrm{g}}\end{array}$ & 50 & $\begin{array}{c}\text { Different } \\
\text { database } \\
\text { variables are } \\
\text { linked }^{k}\end{array}$ & Real-time & No & Yes \\
\hline Slovenia & Yes & $\begin{array}{l}\text { CART-experienced } \\
\text { with HIVc }\end{array}$ & $\begin{array}{l}\text { Cross- } \\
\text { sectional }^{d}\end{array}$ & $\begin{array}{l}\mathrm{DR}^{\mathrm{e}} / \text { subtype }^{\mathrm{f}} / \\
\text { transmission }^{\mathrm{g}}\end{array}$ & 50 & $\begin{array}{l}\text { Complete or full } \\
\text { data linkage }\end{array}$ & Annually & Yes & Yes \\
\hline Spain & No & $\begin{array}{l}\text { CART-naive newly } \\
\text { HIV diagnosed }{ }^{\mathrm{b}} \text { and } \\
\text { CART-naïve } \\
\text { initiating first line } \\
\text { CART' }^{\mathrm{s}}\end{array}$ & $\begin{array}{l}\text { Cross- } \\
\text { sectional }^{d}\end{array}$ & Not applicable & No data & Not applicable & NA & No & No data \\
\hline Sweden & No & $\begin{array}{l}\text { CART-naive newly } \\
\text { HIV diagnosed }{ }^{\mathrm{b}} \text { and } \\
\text { cART-experienced } \\
\text { with HIV' and } \\
\text { CART-naïve } \\
\text { initiating first line } \\
\text { CART' }\end{array}$ & Longitudinal $^{\mathrm{h}}$ & $\mathrm{DR}^{\mathrm{e}} /$ subtype $^{\mathrm{f}}$ & 65 & $\begin{array}{l}\text { Data are } \\
\text { submitted on } \\
\text { a case by case } \\
\text { level but not } \\
\text { linked }\end{array}$ & $\begin{array}{l}\text { For clinical } \\
\text { purpose } \\
\text { mainly }\end{array}$ & Yes & No data \\
\hline $\begin{array}{l}\text { United } \\
\text { Kingdom }\end{array}$ & Yes & $\begin{array}{l}\text { CART-naive newly } \\
\text { HIV diagnosed }{ }^{b} \text { and } \\
\text { CART-experienced } \\
\text { with HIV }{ }^{c} \text { and } \\
\text { CART-naïve } \\
\text { initiating first line } \\
\text { CART' }\end{array}$ & Longitudinal $^{\mathrm{h}}$ & $\begin{array}{l}\text { DRe/subtype } / \\
\text { transmission }^{\mathrm{g}}\end{array}$ & 70 & $\begin{array}{c}\text { Different } \\
\text { database } \\
\text { variables are } \\
\text { linked }^{k}\end{array}$ & Annual & & \\
\hline
\end{tabular}

CART: combination antiretroviral therapy; DR: drug resistance; MSM: men who have sex with men; NA: not available; SPREAD: Strategy to Control SPREAD of HIV Drug Resistance.

${ }^{a}$ Data are not linked and are available on an aggregated level only.

${ }^{b}$ All CART-naive individuals newly diagnosed with HIV.

c All cART-experienced individuals with a detectable HIV load.

${ }^{d}$ Only one sequence per individual is collected.

e Monitoring HIV DR.

${ }^{\mathrm{f}}$ Assess HIV subtypes.

${ }^{\mathrm{g}}$ Conduct phylogenetic analysis of transmission events.

${ }^{\mathrm{h}}$ Longitudinal in a cohort; multiple sequences per individual can be collected.

' Integrated clinical, epidemiological and virological data are submitted on a case-by-case level.

i All CART naïve individuals initiating first line cART.

${ }^{k}$ Clinical, epidemiological and laboratory variables from different databases are linked.

In the 2016 update to the European Centre for Disease Prevention and Control (ECDC)'s roadmap for integration of molecular typing into European-level surveillance and epidemic preparedness, HIV was highlighted as a pathogen for which more evidence on the challenges and opportunities of implementing surveillance based on molecular typing data was required before establishing a common approach to monitor HIV DR in Europe [16]. HIV DR analysis is based on genotypic and/or phenotypic testing and therefore molecular typing data are required for DR surveillance [17]. In order to inform the feasibility of and the most appropriate approach to implement an EU-level surveillance of HIV $\mathrm{DR}$, we conducted a survey to assess the laboratory capacity and needs regarding molecular surveillance of HIV in EU/EEA countries. 
TABLE 2

Estimated proportion of new HIV diagnoses in European Union countries with sequence data, 2015 ( $\mathrm{n}=21)$

\begin{tabular}{|c|c|c|c|}
\hline Country & $\begin{array}{l}\text { Estimated number of HIV sequences } \\
\text { collected in } 2015^{\mathrm{a}}\end{array}$ & $\begin{array}{l}\text { Number of new HIV diagnoses } \\
\text { reported in } 2015^{\mathrm{b}}\end{array}$ & $\begin{array}{l}\text { Estimated \% of new HIV diagnoses } \\
\text { with sequence data }\end{array}$ \\
\hline Austria & No data & 264 & Not calculable \\
\hline Belgium & Between 500 and 999 & 1,001 & 75 \\
\hline Croatia & Less than 100 & 117 & 43 \\
\hline Cyprus & No data & 80 & Not calculable \\
\hline Czech Republic & Between 100 and 199 & 266 & 56 \\
\hline Denmark & Between 100 and 199 & 277 & 54 \\
\hline Finland & Between 100 and 199 & 174 & 86 \\
\hline France & Between 500 and 999 & 3,943 & 19 \\
\hline Germany & Over 2,000 & 3,674 & Not calculable \\
\hline Hungary & Less than 100 & 271 & $19^{c}$ \\
\hline Ireland & Between 500 and 999 & 486 & $65^{c}$ \\
\hline Italy & Between 200 and 499 & 3,444 & 10 \\
\hline Latvia & Between 100 and 199 & 393 & 38 \\
\hline Netherlands & Between 200 and 499 & 802 & 44 \\
\hline Poland & Between 200 and 499 & 1,275 & 27 \\
\hline Romania & Between 100 and 199 & 756 & 20 \\
\hline Slovakia & Between 100 and 199 & 86 & 100 \\
\hline Slovenia & Less than 100 & 48 & $50^{c}$ \\
\hline Spain & No data & 3,428 & Not calculable \\
\hline Sweden & Between 200 and 499 & 447 & 78 \\
\hline United Kingdom & Over 2,000 & 6,078 & Not calculable \\
\hline
\end{tabular}

${ }^{a}$ The midpoint of the range was used to estimate the proportion of new HIV diagnoses with sequence data.

${ }^{b}$ Data were obtained from TESSy [20].

' Country directly provided \% of new HIV diagnoses with sequence data.

\section{Methods}

28 EU countries, Iceland and Norway (EU/EEA) were invited to participate in an online survey (created with EUSurvey tool [18]) on HIV molecular surveillance capacity in July 2016. As this survey investigated both surveillance systems and laboratory elements, National Focal Points for HIV/AIDS, sexually transmitted infections and hepatitis $\mathrm{B} / \mathrm{C}$ as well as the National Focal Points for microbiology were invited to collaborate and complete the questionnaire. Questions covered sampling strategy, use of HIV sequence data at national level, HIV surveillance indicators, methods for HIV antiviral resistance testing, and whether national reports are produced. Reminder emails were sent to non-responders and data submission was accepted until September 2016.

The surveillance section included questions on the purpose of HIV sequence data collection, criteria used for inclusion and exclusion of cases in national HIV molecular surveillance systems, surveillance indicators used and on how and to whom surveillance data were reported. The laboratory section addressed areas including methods used and the management and reporting of laboratory data. The final section of the survey included questions on resources required by countries to perform HIV sequence analysis and to regularly report HIV DR and subtype data, as well as on potential obstacles to setting up an EU-wide surveillance system.

Counts and proportions of country responses to survey questions were calculated using $R$ version 3.2.4, R Foundation for Statistical Learning, Vienna, Austria. Maps were generated using ECDC Map Maker (EMMa) [19]. Survey data were supplemented with HIV surveillance data submitted to the European Surveillance System (TESSy) for 2015 [20].

The results of the survey were discussed at an ECDC expert consultation meeting 27-28 October 2016, which was attended by HIV surveillance and DR experts from the EU, Switzerland and the WHO.

\section{Results}

A total of 21 of $30 \mathrm{EU} / \mathrm{EEA}$ countries responded to this survey. An overview of the uses of HIV sequence data at national level across the EU can be seen in the Figure. About two thirds of responding countries $(n=13$ countries) reported using HIV sequence data for surveillance purposes. Nineteen countries reported that HIV sequence data are used at national level for monitoring of HIV DR. In addition, 19 and 15 countries use HIV sequence data at national level for assessment 
of HIV subtype and phylogenetic analysis of transmission events respectively.

A summary of the survey findings on the key elements of HIV molecular surveillance and reporting in the EU is presented in Table 1 . Differences were found in the patients selected for sequence-based characterisation of HIV. Of 19 countries that reported using HIV sequence data at national level to monitor HIV DR, 12 countries obtain samples for sequence-based characterisation from cART-naïve individuals newly diagnosed with HIV, nine countries obtain samples from both CART-naïve individuals newly diagnosed with HIV and CART-experienced individuals with detectable HIV load. Seven countries performed longitudinal collection (collection of multiple sequences per individual), six cross-sectional collection (collection of one sequence per individual) of HIV sequences, and an additional two countries reported cross-sectional and longitudinal sequence collection. Twelve countries were able to estimate the national coverage of HIV sequence data, which ranged from 15 to $100 \%$ of individuals who met the case definition of HIV.

Among 13 countries reporting using HIV sequence data for surveillance (subtype and/or DR), nine stated that linkage between clinical, epidemiological and sequence data with one or more databases took place (Table 1). Of those, seven countries reported integration of clinical, epidemiological and virological data at case level.

Moreover, among the 13 using HIV sequence data for surveillance, seven countries stated that they report sequence data annually, four in real time, one monthly and one did not address this question. SPREAD was the most commonly reported project to which countries performing surveillance of HIV sequences submitted HIV DR data ( $n=8$ countries). Eight of 13 countries performing molecular surveillance of HIV stated that they produced a national HIV DR report.

\section{Surveillance system}

Of 13 countries performing molecular surveillance of HIV, 11 stated that they employed a number of different strategies for the surveillance of HIV sequence data at national level. Eleven countries reported that they perform resistance testing based on samples routinely generated in clinical practice. Specific cohorts/ projects were the second most highly reported sample source ( $n=6$ countries). Seven countries stated that they believed that their sampling strategy was fully representative for the national HIV epidemic. Three countries reported that sampling was representative for specific regions. No country stated that they used a specific sample size calculation method for estimating the prevalence of DR at national level for extrapolating the measured prevalence to estimate the true population prevalence (number of cases).
As seen in Table 2, 18 of 21 countries participating in the current study, were able to provide an estimate of the numbers of sequences collected at national level in 2015, with answers ranging from less than 100 sequences to more than 2,000. Comparison of these estimates of HIV sequence data with HIV surveillance data submitted to TESSy in 2015, and assuming one sequence was collected per newly diagnosed individual, revealed country-specific proportions of new HIV diagnoses with sequence data ranging from 10 to $100 \%$.

Of the 13 countries performing molecular surveillance of HIV, ten stated that surveillance indicators are used for HIV molecular surveillance. The most commonly reported indicators were (i) the proportion of sequences available among all newly reported HIV cases in a given year ( $n=10$ countries), (ii) the proportion of non-B subtype sequences among all reported sequences in a given year ( $n=10$ countries), and (iii) the proportion of available sequences with relevant resistance mutations according to the Stanford HIV Drug resistance ( $n=9$ countries). The most frequently reported inclusion criteria for HIV molecular surveillance were: CART-naïve individuals newly diagnosed with HIV ( $\mathrm{n}=6$ countries) and cART-experienced individuals with detectable HIV load ( $\mathrm{n}=4$ countries). Samples without known HIV RNA level ( $n=7$ countries) and an HIV viral load of less than 1,000 copies $/ \mathrm{mL}$ ( $n=5$ countries) were reported as the primary exclusion criteria for not collecting HIV sequences. In terms of collection of HIV sequence data, nine countries reported continuous collection of generated sequences and three reported continuous collection of samples with retrospective batch-wise sequence analysis.

\section{Laboratory}

Based on the survey, the most frequently reported specimens taken for HIV sequence analysis among countries performing HIV molecular surveillance ( $n=13$ countries) were ethylenediaminetetraacetic acid (EDTA)-plasma ( $n=10$ countries). All countries used population sequence analysis to generate their sequence data. Three countries also reported using next-generation sequencing (NGS) analysis to generate their HIV sequence data. The Rega HIV subtyping tool ( $n=6$ countries) and the Stanford HIV Drug resistance database ( $n=3$ countries) were the most widely reported tools for subtype analysis. There was little difference among countries in the genes used for HIV genome sequencing, with protease ( $n=13$ countries), reverse transcriptase ( $n=13$ countries) and integrase ( $n=11$ countries) being the most commonly reported genes sequenced.

Ten countries performing molecular surveillance of HIV stated that laboratories report HIV sequences. Eleven countries stated that HIV sequence data were reported at the nucleotide level and one at amino acid level. The primary database types used for storage of HIV 
sequence data were Excel ( $n=3$ countries), SQL $(n=2$ countries) and Access ( $n=2$ countries).

\section{Resources and obstacles}

Within the 21 countries participating in the current study, a change of guidelines/policy ( $n=10$ countries) and additional personnel ( $n=10$ countries) were highlighted as key resources needed to implement HIV sequence analysis. No further explanation was provided by any country on the type of guideline/policy changes needed to implement HIV sequence analysis. Database solutions ( $\mathrm{n}=8$ countries), data entry capacity and data transfer ( $\mathrm{n}=6$ countries) and support in data analysis ( $n=5$ countries) were the main types of technical support required for the implementation of regular reporting of HIV DR data. Similar results were found for the reporting of HIV subtype data. Among the 12 countries that do not currently report HIV DR at national level, database solutions ( $n=5$ countries) and support in data analysis ( $n=5$ countries) were the most frequently highlighted technical support requirements.

There was no clear preferred reporting format for HIV DR in the EU. Aggregated reporting of DR prevalence data per drug ( $n=9$ countries) or case- and (nucleotide level) sequence-based reporting ( $n=7$ countries) were both similarly preferred formats. Respondents disagreed on the most appropriate strategy to implement molecular surveillance of HIV in countries without existing HIV molecular surveillance ( $n=8$ countries). Two of these eight countries supported periodic surveys on pre-treatment or acquired resistance, one country supported sentinel sampling based on agreed standards and indicators and another supported comprehensive collection of case-based HIV resistance data. No country elaborated further on their preferred strategy to implement molecular surveillance of HIV. Among the 21 countries participating, a number of obstacles to sharing national sequence data at international level were highlighted: human resources ( $n=13$ countries), database compatibility ( $n=13$ countries), data ownership ( $n=13$ countries), ethical ( $n=9$ countries) and legal issues ( $n=9$ countries) were the most frequently reported.

\section{Discussion}

The results of this survey provide an overview of the current status of HIV molecular surveillance in the EU. Thirteen of the 21 responding countries reported that they are already using sequence data for the surveillance of HIV to some extent, with a number of countries also submitting HIV sequence data to the SPREAD project and/or including HIV DR data in national surveillance reports. Several differences between national HIV molecular surveillance systems were noted, including criteria used for inclusion and exclusion of cases in national HIV molecular surveillance systems, however, similarities between systems were also found (e.g. data linkage, populations under surveillance and laboratory methods used). Knowledge of these similarities and differences will be used to inform a pilot study on HIV DR surveillance in the EU.

This study also identified some similarities in the needs of EU countries for performing and regularly reporting HIV sequence data, as well as in the opinions on the obstacles for submitting national sequence data to the international level among participating countries. Human resources, data management, legal and ethical issues could pose significant challenges to establishing an EU-wide molecular surveillance system. However, these issues are not perceived to be absolute obstacles to a phased implementation of a HIV molecular surveillance system, where countries could submit data as and when it became feasible for them to do so. The Centers for Disease Prevention and Control (CDC) in the United States (US) have similarly highlighted that legislative issues need to be considered in relation to HIV DR surveillance, such as review and potentially revision of State or local HIV laws and regulations to ensure reporting of HIV nucleotide sequence data at national level [21]. The WHO Global Action Plan on HIV drug resistance highlighted similar challenges faced by countries when implementing HIV DR surveillance, including issues related to data ownership, laboratory capacity, human resources, competing public health priorities and national regulations [10].

Across EU countries, considerable variation was found in the estimated proportion of new HIV diagnoses for which sequence data were available. These differences may reflect the sampling strategies applied to surveillance of HIV sequence data across the EU. However, these estimates must be considered with caution, as countries provided a range for the estimate of the number of HIV sequences collected and the midpoint of this range was used for calculation purposes. Moreover longitudinal sampling was not taken into account.

The SPREAD project has performed HIV DR surveillance in Europe for more than 10 years, and has shown that TDR prevalence has stabilised at ca 8\%, from 2002 to 2010 , while also reporting an increase in resistance to specific drug classes $[13,14,22]$. A meta-analysis by Rhee et al. reported a similar overall TDR prevalence of 9.4\% in Europe between 2000 and 2013 [23]. Individual country reports from Belgium 2014, Ireland 2015 and France 2009 have shown a similar stabilising of the prevalence of TDR over time [24-26]. However, analyses from Switzerland have shown fluctuation in TDR prevalence between 1995 and 2012, with reductions over time likely due to the introduction of new drug classes [27]. The Swiss study emphasised the need for continuous development and widespread distribution of new drugs in order to reduce TDR prevalence. Furthermore, analysis of HIV DR surveillance data in the Netherlands allowed researchers to better understand transmission clusters among men who have sex with men (MSM) [28]. They identified self-sustaining HIV clusters that were present since the 1990 s and emphasised the need for intensified efforts to prevent further infections. 


\section{Weaknesses and limitations}

The results of this study need to be considered in light of the survey's limitations. Firstly, the overall response rate was $21 / 30$, which may have been negatively influenced by the timing of the survey (during the summer period). It is more likely that those countries with something positive to report in this field would have responded, leading to a slight overestimation of the true proportions in the EU. The results do not therefore provide a full understanding of HIV molecular surveillance capacity in the EU. Secondly, the accuracy of the content is very much dependent on who has been tasked to fill in the data and there may be some variability due to incomplete knowledge of the situation by the respondent. Thirdly, only rough estimates of the proportion of HIV cases with sequence data could be calculated due to the nature of the data available. Finally, caution is needed when interpreting the data on HIV molecular surveillance capacity, as countries performing HIV molecular surveillance represent just under half of the total number of EU countries and no data on HIV molecular surveillance capacity were obtained from seven EU or any EEA countries.

\section{The way forward}

The results of this survey were presented and discussed at an ECDC expert consultation meeting. It was broadly agreed that ECDC could have an important role in establishing a formal HIV DR surveillance system, through standardisation of the reporting procedure and by helping reduce some of the reporting issues identified in the survey. However, more structural barriers to performing HIV DR surveillance including human resources, ethical considerations and changes in guidelines/policy could only be addressed at a national level. The objectives for HIV DR monitoring at EU/EEA level, and the scope and format of an EU/ EEA surveillance system for HIV DR monitoring were key items discussed at this meeting. Estimating TDR prevalence among newly diagnosed individuals was generally supported as a primary objective for an EU/ EEA-wide HIV DR system, which is similar to that of the US CDC's Molecular HIV Surveillance (MHS) system and Australia's HIV DR surveillance reporting [21,29]. There was a general consensus that a pilot study on collection of HIV DR data should be conducted, which should focus on a limited number of countries that already collect HIV DR data and are able to link it to demographic data. The pilot study will serve to explore the feasibility of standardising reporting, an agreement for a European surveillance protocol and evaluation of representativeness of the studied population. The outcomes of the pilot study will be discussed within the European HIV surveillance network and establishment of European HIV DR surveillance will be agreed with the countries that can adjust their national policies. Currently, HIV DR surveillance is not planned to be mandatory for EU countries.

In conclusion, this survey has identified some capacity for HIV DR surveillance in the EU, but also important challenges that will take time to address. The next steps will involve the conduct of a pilot study of HIV DR surveillance in selected EU countries. The phased implementation of a HIV DR surveillance system in the EU/EEA should allow better data for monitoring of HIV DR over time, by drug class, among risk groups and by geographic location. This will allow for a better understanding of HIV DR, which is of primary concern for public health since it has the potential to impact the success of first-line cART regimens, resulting both in potentially negative patient outcomes and the potentially higher CART treatment costs associated with second or third-line regimens.

\section{Acknowledgements}

We acknowledge all survey participants from the following countries:

Austria: Elisabeth Puchhammer-Stöckl (Medical University Vienna, Vienna)

Belgium: Katrien Fransen (Institute of Tropical Medicine, Antwerp)

Croatia: Snjezana Zidovec Lepej (University Hospital for Infectious Diseases “Dr. Fran Mihaljevic”)

Cyprus: Linos Hadjihannas (Ministry of Health of the Republic of Cyprus, Nicosia)

Czech Republic: Vratislav Nemecek (National Reference Laboratory for HIV / AIDS in National Institute of Public Health, Prague)

Denmark: Jannik Fonager (Statums Serum Institut, Copenhagen)

Finland: Kirsi Liitsola (National Institute for Health and Welfare, Helsinki)

France: Florence Lot and Francis BARIN (Santé publique France / National Reference Center for HIV, Paris)

Germany: Barbara Bartmeyer (Robert Koch-Institute, Berlin)

Hungary: Maria Mezei (National Centre for Epidemiology, Budapest)

Ireland: Dr Cillian De Gascun (1); Dr Suzie Coughlan (1); Dr Derval Igoe (2); Dr Eve Robinson (2)

(1. National Virus Reference Laboratory (NVRL); 2. Health Protection Surveillance Centre (HPSC), Dublin)

Italy: Stefano Buttò (Istituto Superiore di Sanità, Rome)

Latvia: Tatjana Kolupajeva (Riga East University Hospital, and the Latvian Centre of Infectious Diseases and the National Microbiology Reference Laboratory, Riga)

The Netherlands: Birgit van Benthem (National Institute of Public Health and the Environment, Utrecht)

Poland: Rosinska Magdalena (National Institute of Public Health - National Institute of Hygiene, Warsaw)

Romania: Dan Otelea (National Institute for Infectious Diseases, Bucharest) 
Slovakia: Danica Staneková (NRC for HIV/AIDS prevention, Slovak Medical University, Bratislava)

Slovenia: Mario Poljak (Institute of Microbiology and Immunology, Faculty of Medicine, University of Ljubljana, Ljubljana)

Spain: Miguel Thomson and Asuncion Diaz (National Centre of Microbiology /National Centre of Epidemiology (Instituto de Salud Carlos III), Madrid)

Sweden: Maria Axelsson (Public Health Agency of Sweden, Stockholm)

United Kingdom: Jean Lutamyo Mbisa (Public Health England, London)

We have received valuable comments to the study protocol and the manuscript from Julien Beauté, Phillip Zucs, Denis Coulombier and Mike Catchpole and acknowledge their contribution in improving the paper.

\section{Conflict of interest}

None declared.

\section{Authors' contributions}

PK analysed and validated the data and drafted the manuscript. EB, AP, KL, AW and AJA-G designed the questionnaire and $E B, A P, K L$ and $A J A-G$ initiated and developed the study. SDA set up the questionnaire, collected the data and was in contact with country representatives during the data collection. PK and EB responded to reviewers' comments to the manuscript. All authors contributed to the concept of the manuscript and reviewed it critically. All authors have read and approved the final manuscript.

\section{References}

1. World Health Organization (WHO). Consolidated guidelines on the use of antiretroviral drugs for treating and preventing HIV infection: recommendations for a public health approach. Geneva: WHO; 2016. Available from: http://www.who.int/hiv/ pub/arv/arv-2016/en/

2. UNAIDS. 90-90-90 An ambitious treatment target to help end the AIDS epidemic. Geneva: UNAIDS; 2014.

3. UNAIDS. Global AIDS update 2016. Geneva: UNAIDS; 2016.

4. UNAIDS. Oral pre-exposure prophylaxis: putting a new choice in context. Geneva: UNAIDS; 2015.

5. Gupta RK, Jordan MR, Sultan BJ, Hill A, Davis DHJ, Gregson J, et al. Global trends in antiretroviral resistance in treatment-naive individuals with HIV after rollout of antiretroviral treatment in resource-limited settings: a global collaborative study and meta-regression analysis. Lancet. 2012;380(9849):12508. https://doi.org/10.1016/S0140-6736(12)61038-1 PMID: 22828485

6. Spira S, Wainberg MA, Loemba H, Turner D, Brenner BG. Impact of clade diversity on HIV-1 virulence, antiretroviral drug sensitivity and drug resistance. J Antimicrob Chemother. 2003;51(2):229-40. https://doi.org/10.1093/jac/dkg079 PMID: 12562686

7. Preston BD, Poiesz BJ, Loeb LA. Fidelity of HIV-1 reverse transcriptase. Science. 1988;242(4882):1168-71. https://doi. org/10.1126/science.2460924 PMID: 2460924

8. Bebenek K, Abbotts J, Roberts JD, Wilson SH, Kunkel TA. Specificity and mechanism of error-prone replication by human immunodeficiency virus-1 reverse transcriptase. J Biol Chem. 1989;264(28):16948-56. PMID: 2476448

9. Clutter DS, Jordan MR, Bertagnolio S, Shafer RW. HIV1 drug resistance and resistance testing. Infect Genet Evol. 2016;46:292-307. https://doi.org/10.1016/j. meegid.2016.08.031 PMID: 27587334

10. World Health Organization (WHO). Global Action Plan on HIV Drug Resistance 2017-2021. Geneva: WHO;
2017. Available from: http://apps.who.int/iris/bitstre am/10665/255883/1/9789241512848-eng.pdf?ua=1

11. Phillips AN, Stover J, Cambiano V, Nakagawa F, Jordan MR, Pillay D, et al. Impact of HIV Drug Resistance on HIV/AIDSAssociated Mortality, New Infections, and Antiretroviral Therapy Program Costs in Sub-Saharan Africa. J Infect Dis. 2017;215(9):1362-5. https://doi.org/10.1093/infdis/jixo89 PMID: 28329236

12. World Health Organization (WHO). HIV drug resistance surveillance guidance: 2015 update. Geneva: WHO; 2015. Available from: apps.who.int/iris/ bitstream/10665/204471/1/9789241510097_eng.pdf?ua=1.

13. Frentz D, Van de Vijver DAMC, Abecasis AB, Albert J, Hamouda 0 , Jørgensen LB, et al. Increase in transmitted resistance to non-nucleoside reverse transcriptase inhibitors among newly diagnosed HIV-1 infections in Europe. BMC Infect Dis. 2014;14(1):407. https://doi.org/10.1186/1471-2334-14-407 PMID: 25047543

14. Hofstra LM, Sauvageot N, Albert J, Alexiev I, Garcia F, Struck D, et al. Transmission of HIV Drug Resistance and the Predicted Effect on Current First-line Regimens in Europe. Clin Infect Dis. 2016;62(5):655-63. https://doi.org/10.1093/cid/civ963 PMID: 26620652

15. Sista P, Rinehart A, Wasikowski B, Winters B, Pattery T, Bacheler L. Nine-year trends in clinically relevant reduced susceptibility of HIV-1 to antiretrovirals. J Clin Virol. 2009;44(3):190-4. https://doi.org/10.1016/j.jcv.2008.12.005 PMID: 19168389

16. European Centre for Disease Prevention and Control (ECDC). The 2016 ECDC roadmap for integration of molecular and genomic typing into European level surveillance and epidemic preparedness Version 2.1, 2016-19. Stockholm: ECDC; 2016.

17. Shafer RW, Dupnik K, Winters MA, Eshleman SH. A Guide to HIV-1 Reverse Transcriptase and Protease Sequencing for Drug Resistance Studies. HIV Seq Compend. 2001;2001:1-51. PMID: 22324021

18. EUsurvey. Available from: https://ec.europa.eu/eusurvey/

19. European Centre for Disease Control and Prevention (ECDC). ECDC Map Maker (EMMa). Stockhom: ECDC. [Accessed 27 Jul 2017]. Available from: https://emma.ecdc.europa.eu/

20. European Centre for Disease Prevention and Control (ECDC) / World Health Organization Regional Office for Europe. HIV/ AIDS surveillance in Europe in 2015; 2016.

21. Centers for Disease Control and Prevention (CDC). Technical Guidance for HIV surveillance programs: Molecular HIV Surveillance (MHS). Atlanta: CDC; 2012. Available from: https://www.vdh.virginia.gov/epidemiology/ DiseasePrevention/Programs/HIV-AIDS/SurveillanceProgram/ documents/pdf/Final Att-4d MHS Tech Guidance.pdf

22. SPREAD programme. Transmission of drug-resistant HIV-1 in Europe remains limited to single classes. AIDS. 2008;22(5):625-35. https://doi.org/10.1097/ QAD.obo13e3282f5e062 PMID: 18317004

23. Rhee S-Y, Blanco JL, Jordan MR, Taylor J, Lemey P, Varghese $\mathrm{V}$, et al. Geographic and temporal trends in the molecular epidemiology and genetic mechanisms of transmitted HIV-1 drug resistance: an individual-patient- and sequence-level meta-analysis. PLoS Med. 2015;12(4):e1001810. https://doi. org/10.1371/journal.pmed.1001810 PMID: 25849352

24. Health Service Executive (HSE). HIV in Ireland - 2015 report. Dublin: HSE; 2016.

25. Chaix M-L, Descamps D, Wirden M, Bocket L, Delaugerre C, Tamalet $C$, et al. Stable frequency of HIV-1 transmitted drug resistance in patients at the time of primary infection over 1996-2006 in France. AIDS. 2009;23(6):717-24. PMID: 19279445

26. Institut scientifique de Santé publique. Epidémiologie du SIDA et de l'infection à VIH en Belgique. Brussels; 2014.

27. Yang W-L, Kouyos R, Scherrer AU, Böni J, Shah C, Yerly S, et al. Assessing the Paradox Between Transmitted and Acquired HIV Type 1 Drug Resistance Mutations in the Swiss HIV Cohort Study From 1998 to 2012. J Infect Dis. 2015;212(1):28-38. https://doi.org/10.1093/infdis/jiv012 PMID: 25576600

28. Bezemer D, Cori A, Ratmann O, van Sighem A, Hermanides HS, Dutilh BE, et al. ATHENA observational cohort. Dispersion of the HIV-1 Epidemic in Men Who Have Sex with Men in the Netherlands: A Combined Mathematical Model and Phylogenetic Analysis. PLoS Med. 2015;12(11):e1001898, discussion e1001898. https://doi.org/10.1371/journal. pmed.1001898 PMID: 26529093

29. Kirby Insitute. HIV in Australia Annual Surveillance Report 2014 Supplement. Sydney; 2014. Available from: https://kirby.unsw. edu.au/sites/default/files/hiv/resources/HIVASRsuppl2014_ online.pdf 


\section{License and copyright}

This is an open-access article distributed under the terms of the Creative Commons Attribution (CC BY 4.0) Licence. You may share and adapt the material, but must give appropriate credit to the source, provide a link to the licence, and indicate if changes were made.

This article is copyright of the authors, 2017. 